\title{
SEBARAN BENTENG KOLONIAL EROPA DI PESISIR BARAT \\ PULAU HALMAHERA: JEJAK ARKEOLOGIS DAN SEJARAH PEREBUTAN WILAYAH DI KESULTANAN JAILOLO
}

\author{
Distribution of European Colonial Fortress in Coastal \\ of West Halmahera Island: Archaeological Traces and History of Annexation \\ in the Sultanate Jailolo Region
}

\author{
Syahruddin Mansyur \\ Balai Arkeologi Maluku \\ Jalan Namalatu-Latuhalat, Nusaniwe, Ambon 97118 \\ E-mail: hitam_putih07@yahoo.com
}

Naskah diterima redaksi: 13 Mei 2016 - Revisi terakhir: 20 Oktober 2016

Naskah disetujui terbit: 28 November 2016

\begin{abstract}
The range of European domination in North Maluku had been traced by the distribution of archaeological fortress. The distribution of fortress in Northern Maluku can be found in the west coast of Halmahera Island as the center in past periode of the Sultanate Jailolo. Based on the background, this paper aims to reveal the distribution of fort on the west coast of Halmahera and historical context of the distribution of the fort in the region. Through descriptive method by using historical analogies approach obtained a description of the distribution pattern of the fort and the role of regions based on the position of forts on the western coast of Halmahera. At least, there are eight locations of those fortress, such as Gamkonora, Sahu, Gofasa, Gamlamo/Jailolo, Sidangoli, Dodinga, Oba, and Payahe. The role of each points of this location has different function and, including Gamkonora and Sahu at the north and Dodinga and Oba which is located in the south serves as a surveillance area to keep Gufasa and Gamlamo fortress in the middle. Based on the distribution data can be seen the role of fortress each other Gamlamo as a center of power Jailolo, Sahu as buffer zones, as well Dodinga and Gamkonora as a fortress of frontier guards.
\end{abstract}

Keywords: castle, colonial, Sultanate Jailolo

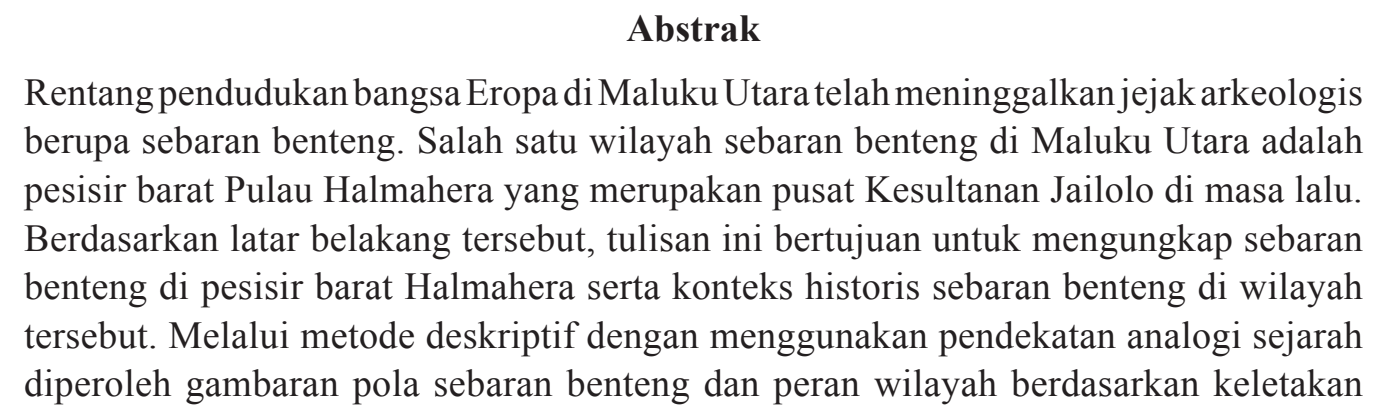


lokasi benteng di pesisir barat Halmahera. Setidaknya terdapat delapan titik lokasi sebaran benteng, yaitu Gamkonora, dua benteng di Sahu, Gufasa, Gamlamo/Jailolo, Sidangoli, Dodinga, Oba, dan Payahe. Titik-titik lokasi ini memiliki fungsi dan peran masing-masing, di antaranya Gamkonora dan Sahu yang berada di utara serta Dodinga dan Oba yang berada di selatan berfungsi sebagai wilayah pengawasan untuk menjaga Benteng Gofasa dan Gamlamo yang berada di bagian tengah. Berdasarkan sebaran data tersebut diperoleh gambaran tentang peran masing-masing benteng yaitu Gamlamo sebagai pusat kekuasaan Jailolo, Sahu sebagai wilayah penyangga, serta Gamkonora dan Dodinga sebagai benteng penjaga tapal batas.

Kata kunci: benteng, kolonial, Kesultanan Jailolo

\section{PENDAHULUAN}

Jailolo adalah salah satu dari empat pilar kekuasaan di Maluku Utara yang tumbuh dan berkembang sejak periode abad ke-13 hingga abad ke-17. Empat pilar kekuasaan yang disebut Moluco Kie Raha ini adalah Kesultanan Jailolo, Kesultanan Bacan, Kesultanan Tidore, dan Kesultanan Ternate. Awal pertumbuhan sebagai satu pilar kekuasaan dalam Moluco Kie Raha bermula dari keberhasilan Jailolo menguasai hampir seluruh wilayah Pulau Halmahera sejak abad ke-13. Sejak saat itu pula, perjalanan sejarah Jailolo sering mendapat ancaman dan ekspansi terutama dari pihak Ternate hingga mengalami keruntuhan pada abad ke-17. Setidaknya terdapat dua serangan besar yang dilancarkan oleh pihak Ternate (dibantu oleh sekutu bangsa Eropa), yaitu tahun 1551 (bersama Portugis), dan tahun 1620 (bersama Belanda). Para ahli sejarah berpandangan bahwa dua serangan ini bahkan telah merusak struktur kekuasaan internal Kesultanan Jailolo dan pascakeruntuhan tersebut wilayah Kesultanan Jailolo mengalami pasang surut perebutan wilayah yang tidak hanya melibatkan penguasa lokal tetapi juga bangsa Eropa (Amal, 2010: 15-22; Andaya, 2015: 170).
Menarik jika memperhatikan perjalanan sejarah Jailolo diwarnai dengan perebutan wilayah yang selalu melibatkan bangsa Eropa. Kehadiran bangsa Eropa di wilayah Maluku yang pada awalnya dilatarbelakangi oleh kepentingan ekonomi kemudian ikut berperan dalam perebutan wilayah kekuasaan antar penguasa lokal. Pertimbangan utama keikutsertaan bangsa Eropa dalam perebutan wilayah ini tidak lepas dari kemampuan dan penguasaan teknologi perang yang dimiliki saat itu. Salah satunya adalah kemampuan mereka membangun benteng pertahanan dengan struktur yang lebih kuat.

Dalam konteks penelitian arkeologi, wilayah pesisir barat Pulau Halmahera (bagian dari wilayah pusat Kesultanan Jailolo) memiliki potensi sebaran tinggalan arkeologi berupa benteng pertahanan yang dibangun oleh bangsa Eropa. Penelitian arkeologi di pesisir barat Pulau Halmahera telah dilakukan oleh Balai Arkeologi Ambon, yaitu pada 2006, 2009, dan 2015. Penelitian tahun 2006 mengidentifikasi struktur benteng dan makam tua di Gamkonora dan Sahu. Penelitian tahun 2009 merupakan penelitian lanjutan dengan melakukan survei dan ekskavasi di Benteng Say 
Loko/Sabuga yang ada di Lako Akelamo (Sahu). Penelitian tahun 2015 merupakan survei eksploratif untuk mengindentifikasi potensi arkeologi kolonial di pesisir barat Halmahera. Selain itu, Pusat Dokumentasi Arsitektur (PDA) pada tahun 2007 juga telah melakukan kegiatan inventarisasi benteng di wilayah ini. Penelitian lain dilakukan oleh Pusat Arkeologi Nasional pada 2006 yang dititikberatkan pada jaringan perdagangan di wilayah Maluku Utara (Kesultanan Ternate, Tidore, dan Jailolo).

Hasil penelitian yang dilakukan pada 2009 telah dipublikasikan dalam jurnal yang diterbitkan oleh Balai Arkeologi Maluku pada 2010 dengan judul "Perebutan Wilayah pada Masa Transisi Islam-Kolonial di Wilayah Kerajaan Jailolo". Secara umum, tulisan tersebut membahas tentang aktivitas masyarakat sejak masa prakolonial hingga menjelang kehadiran kolonial di wilayah Lako Akelamo (Benteng Say Loko atau Sabuga) yang menjadi bagian dari wilayah kekuasaan Jailolo. Tulisan tersebut juga membahas tentang pendirian benteng kolonial di Lako Akelamo (salah satu wilayah bekas Kesultanan Jailolo) berhubungan dengan perebutan wilayah antara Ternate dan Tidore yang juga melibatkan bangsaEropa(Handoko, 2010: 20-21). Berdasarkan pada hasil kajian tersebut, tulisan ini membahas tentang konteks historis sebaran benteng yang ada di wilayah pusat Kesultanan Jailolo yaitu pesisir barat Pulau Halmahera.

Dalam perspektif arkeologi, sebaran benteng suatu wilayah dapat menjadi data penting dalam merekonstruksi sejarah masa lalu. Demikian halnya dengan data sebaran benteng di wilayah pesisir barat Pulau Halmahera dapat menjadi rujukan untuk merekonstruksi peranperan wilayah yang dulunya menjadi bagian dari Kesultanan Jailolo pada masa keemasannya. Tulisan ini berupaya merangkum hasil-hasil penelitian yang telah dilakukan sebelumnya, yaitu sebaran benteng kolonial yang banyak ditemui di pesisir barat Pulau Halmahera.

Pokok permasalahan yang dibahas dalam tulisan ini adalah sebagai berikut. Pertama, bagaimana pola sebaran benteng di wilayah pesisir barat Pulau Halmahera? Kedua, bagaimana konteks historis benteng-benteng yang ada di wilayah tersebut? Berdasarkan pokok permasalahan tersebut, tulisan ini bertujuan untuk memberi gambaran tentang jejak-jejak arkeologis berupa sebaran benteng yang ada di wilayah pesisir barat Halmahera dan memberi pembahasan yang komprehensif yang dapat menggambarkan perebutan wilayah yang melibatkan baik pihak lokal (Jailolo, Ternate, dan Tidore), maupun pihak asing (Portugis, Spanyol, dan Belanda). Dengan demikian, jawaban dari permasalahan diharapkan dapat mengungkap peran wilayah terkait rekonstruksi sejarah di wilayah Kesultanan Jailolo.

Secara umum, benteng merupakan bangunan yang berfungsi sebagai simbol pertahanan. Akan tetapi, seiring berbagai aktivitas yang dipusatkan dalam benteng sehingga memengaruhi fungsi benteng sebagai pusat administrasi, pemerintahan, dan perdagangan (Marihandono, 2008: 145). Hal ini, karena bentuk benteng berupa tembok (dinding) keliling yang dilengkapi dengan senjata sehingga 
memberi rasa aman terhadap ancaman yang datang dari luar (Mansyur, 2014: 92). Sementara itu, dalam konteks sebaran benteng di suatu wilayah tentu memiliki alasan-alasan yang melatari pemilihan lokasi pendirian sebuah benteng. Novida Abbas (2001), menyebutkan bahwa faktor-faktor yang melatari pemilihan lokasi tersebut, di antaranya

1. Pentingnya suatu daerah pada masa pendirian benteng;

2. Ancaman atau penolakan yang dihadapi;

3. Strategi yang diterapkan dalam upayanya menaklukkan suatu wilayah (Abbas, 2001: 3).

Dalam konteks benteng kolonial Eropa, berdasarkan bentuk dan ukurannya, benteng dapat dikelompokkan menjadi empat jenis, yaitu

1. Pagger: merupakan bentuk sederhana benteng yang hanya dilengkapi dengan pagar kayu keliling;

2. Berdasarkan aspek ukuran dan bentuknya, jenis kedua dapat dikelompokkan dalam dua tipe yaitu Battery/beukery dan redoute. Battery/ beukery adalah bangunan yang berdiri sendiri untuk menempatkan sejumlah meriam, umumnya berbentuk setengah lingkaran atau persegi dengan ukuran $\pm 4 \times 4$ m dengan tinggi $4 \mathrm{~m}$. Sementara redoute, berukuran lebih besar jika dibandingkan dengan battery, \pm 8 hingga $10 \mathrm{~m}$, berbentuk persegi untuk menempatkan meriam.

3. Jenis ketiga yaitu Blockhuis dan Klein fort. Blockhuis, bangunan yang pada awalnya lebih difungsikan sebagai gudang komoditi, umumnya berbentuk persegi. Jenis ini dapat dikembangkan sebagai benteng lengkap dengan bastion dan dapat berfungsi sebagai pos pertahanan. Klein fort, umumnya berbentuk persegi dan memiliki bastion. Jenis ini memiliki ukuran lebih besar dibanding redoute, dan bangunan turutan yang difungsikan sebagai kantor, maupun gudang. Jenis ini lebih mengutamakan fungsi pertahanan;

4. Groote forten/Kasteelen: umumnya berbentuk persegi atau bulat. Jenis ini berukuran lebih besar dibanding klein fort, dengan berbagai fasilitas: kantor, barak, gereja, rumah sakit, dan tempat tinggal. Jenis ini umumnya merupakan embrio kota, seperti Fort Rotterdam di Makassar dan Nieuw Victoria di Ambon (Pusat Dokumentasi Arsitektur, 2008: 5 dan 7; Mansyur, 2011: 25-26).

Ruang lingkup pembahasan dalam tulisan ini dibatasi pada periode kehadiran kolonial Eropa dan ruang lingkup wilayah merujuk pada ruang geografis pesisir barat Pulau Halmahera sebagai wilayah kekuasaan Kesultanan Jailolo pada masa lalu. Adapun metode yang digunakan adalah metode deskriptif untuk memberikan gambaran tentang sebaran data arkeologi, berupa pola sebaran benteng di pesisir barat Halmahera. Selanjutnya digunakan pendekatan analogi sejarah untuk mendukung data arkeologi dalam upaya rekonstruksi sejarah budaya (Ambary, 1998: 151; Sharer and Ashmore, 1980: 445). Dalam hal ini, sumber-sumber sejarah dimaksud baik sumber primer maupun 
sekunder tentang pendirian benteng serta berbagai peristiwa yang berhubungan dengan sejarah benteng. Sumber-sumber ini menjadi rujukan penting kemudian dielaborasi untuk memperoleh informasi konteks historis sebaran benteng. Dengan demikian diperoleh gambaran komprehensif tentang peran wilayah di pesisir barat Pulau Halmahera dalam kaitannya dengan rekonstruksi sejarah Kesultanan Jailolo.

\section{HASIL DAN PEMBAHASAN}

\section{Deskripsi Singkat Benteng-Benteng di Pesisir Barat Pulau Halmahera}

Berdasarkan hasil penelitian di wilayah pesisir barat Halmahera menunjukkan sebagian besar kondisi benteng yang ada hanya menyisakan puing-puing berupa sisa struktur pondasi dan dinding benteng. Titik lokasi keberadaan benteng yang ditemui di lokasi penelitian sebanyak lima lokasi. Kelima titik lokasi benteng ini, yaitu Benteng Sabuga dan Benteng Tabuga di Lako Akelamo; Benteng Sidangoli (Kota Intan); Benteng Dodinga, dan Benteng Gamlamo (Tim Penelitian, 2015).

\section{Benteng Tabuga dan Benteng Sabuga}

Secara administratif, lokasi benteng berada di Desa Lako Akelamo, Kecamatan Sahu Timur, Kabupaten Halmahera Barat. Lokasi benteng juga berada di sebelah selatan Sungai Akelamo yang merupakan sungai terbesar di wilayah Kecamatan Sahu. Saat ini, kedua benteng telah ditetapkan sebagai Cagar Budaya oleh pihak Balai Pelestarian Cagar Budaya (BPCB) Ternate. Terdapat dua titik lokasi struktur, yaitu struktur benteng yang menyisakan bekas pondasi dan struktur lain yang kondisinya lebih baik dengan menyisakan dinding benteng yang utuh.

Informasi tentang pihak yang membangun kedua banteng ini sangat minim dan terdapat beberapa versi yang berbeda. Keterangan yang tampak pada papan informasi sebagai status Cagar Budaya bahwa benteng ini dikenal oleh masyarakat sebagai Benteng Lako Akelamo (nama sungai) yang dibangun oleh Spanyol pada tahun 1548. Sementara itu, van de Wall (1928), tidak menyebut secara langsung siapa dan kapan benteng ini dibangun. Catatan ini hanya menyebut bahwa keterangan paling awal tentang keberadaan benteng ini bersumber dari dokumen yang berasal dari tahun 1608 tanpa menyebutkan isi keterangan tersebut. van de Wall dalam keterangannya lebih banyak menjelaskan pengamatannya tentang kondisi benteng ketika pertama kali ditemukannya.

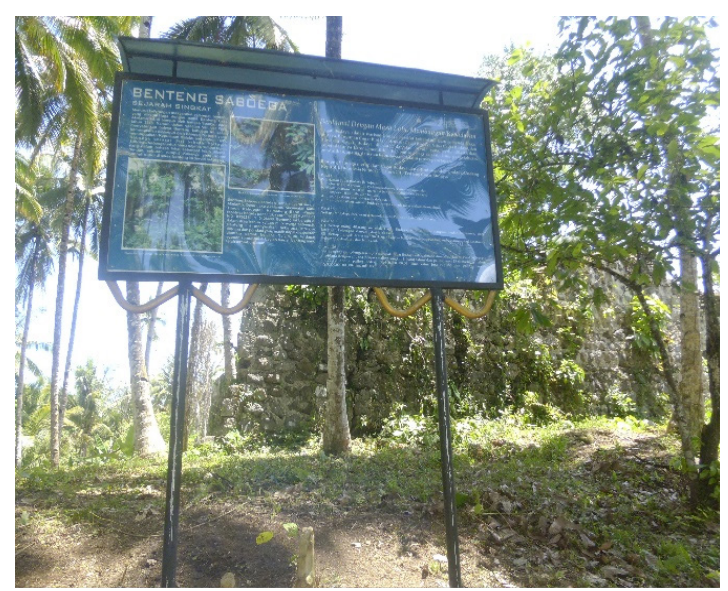

Gambar 1. Benteng Sabuga di Lako Akelamo, Kecamatan Sahu Timur. (Sumber: Dokumen Balai Arkeologi Ambon, 2015)

Informasi lain yang disampaikan bahwa benteng ini berperan penting 
pada masa perang Belanda-Spanyol pada tahun 1611. Saat itu Belanda berhasil menangkap komandan pasukan Spanyol yang berkedudukan di benteng ini. Setelah benteng ini direbut, dan menduduki benteng hingga tahun 1618, Belanda kemudian meninggalkan benteng karena pertimbangan biaya dan kondisi keamanan yang saat itu relatif dapat dikendalikan. Selanjutnya, benteng ini kembali berperan penting dalam perlawanan Sultan Kaitjil Amsterdam sekitar tahun 1679-1681 (de Wall, 1928: 282).

\section{Benteng Sidangilo (Benteng Kota Intan)}

Lokasi benteng berada di tengahtengah permukiman warga Desa Sidangoli Gam, dekat pelabuhan feri Sidangoli. Keterangan pada papan informasi menyebutkan bahwa berdasarkan informasi masyarakat setempat, benteng ini disebut Benteng Kota Intan yang dibangun oleh Portugis sebagai Pos Militer untuk wilayah sekitarnya. Pada tahun 1801, benteng direbut oleh pihak Kesultanan Tidore yang saat itu bersekutu dengan Inggris, kemudian diambil alih oleh Belanda. Informasi tambahan diperoleh dari van de Wall (1928), menyebutkan bahwa kondisi benteng ini telah rusak terutama pada bagian gerbang dan bastionnya. Tidak diketahui kapan benteng ini dibangun, namun tahun 1856 masih terdapat perbaikan pada benteng ini (van de Wall, 1928: 281).

Benteng Sidangoli berhadapan dengan laut yang berada di arah barat laut-tenggara. Saat ini, Benteng Sidangoli hanya menyisakan beberapa struktur dinding dan pondasi benteng. Struktur dinding yang masih tampak jelas adalah sisi barat daya, barat laut, dan timur laut.

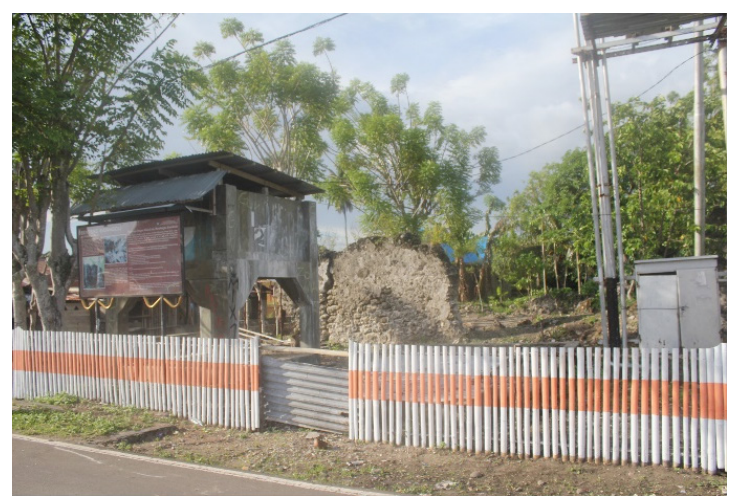

Gambar 2. Sisa struktur Benteng Sidangoli. (Sumber: Dokumen Balai Arkeologi Ambon, 2015)

\section{Benteng Dodinga}

Secara administratif, lokasi benteng berada di Desa Dodinga, Kecamatan Jailolo Selatan. Berbeda dengan bentengbenteng lain yang ada di wilayah Halmahera Barat, benteng ini berada di puncak perbukitan dan berada cukup jauh dari pantai. Orientasi benteng ini adalah utara-selatan, sedangkan arah laut berada di sebelah utara berjarak $\pm 3 \mathrm{~km}$.

Informasi yang diperoleh dari van de Wall (1928), menyebutkan bahwa kondisi benteng telah rusak, kecuali pada satu sisi dinding serta gerbang utama sebelah kiri.

Pada masa pemerintahan Gubernur David Petersom yaitu tahun 1713, benteng ini diduduki untuk menghindari perselisihan perbatasan antara Ternate dan Tidore. Benteng ini juga berperan penting dalam pertempuran melawan Sultan Kaitjil Amsterdam, dan kemungkinan benteng ini dibangun oleh Spanyol (van de Wall, 1928: 281). Selain sisa struktur benteng, juga ditemukan dua meriam 
yang saat ini berada di depan Kantor Desa Dodinga.

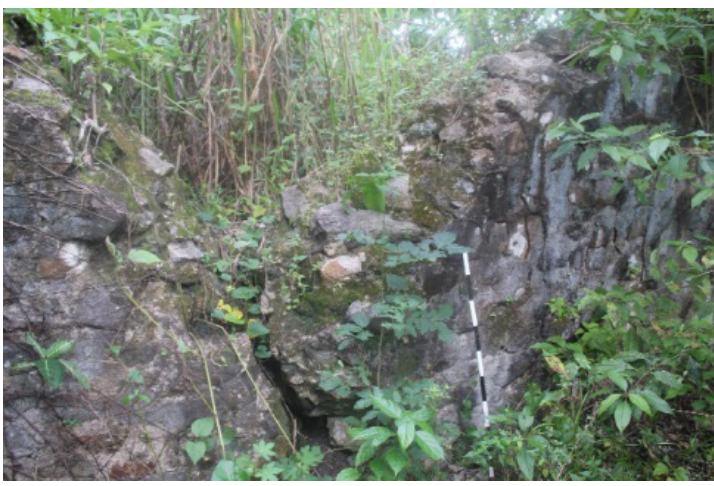

Gambar 3. Struktur dinding benteng yang masih tampak dari reruntuhan benteng Dodinga. (Sumber:

Dokumen Balai Arkeologi Ambon, 2015)

\section{Benteng Gamlamo}

Benteng ini berada di daerah permukiman warga Desa Gamlamo Kecamatan Jailolo dan cukup sulit menemukan struktur yang tersisa karena struktur yang ada hanya bekas reruntuhan dan sisa pondasinya saja. Titik ketinggian benteng ini adalah $24 \mathrm{~m}$ dpl dan berjarak $\pm 5 \mathrm{~km}$ dari pantai. Struktur yang tersisa berada di sisi barat yang kemungkinan merupakan bagian dari bastion, dan di sisi selatan terdapat gundukan tanah tanpa menyisakan sisa struktur. Struktur benteng terdiri dari batu karang dengan spesi campuran pasir dan kapur bakar.

Menurut keterangan yang terdapat pada papan informasi yang ada menyebutkan bahwa benteng ini dibangun oleh Spanyol sebagai basis militer di wilayah Jailolo. Tidak diketahui sejak kapan benteng ini dibangun, namun catatan sejarah menyebut bahwa benteng ini pernah dikuasai oleh Fernao de Saosa de Tavara dan Jenderal Spanyol Roy
Lopez de Villabolos pada tahun 1545. Benteng ini juga pernah dikuasai oleh Raja Jailolo bernama Katarabumi yang kemudian dihancurkan pada 27 Maret 1551 .

Tidak diperoleh informasi tentang keberadaan Benteng Gamlamo dalam hasil inventarisasi yang dilakukan oleh van de Wall tahun 1928. Informasi yang diperoleh tentang benteng di wilayah Kota Jailolo ada Benteng Goefasa yang disebutkan telah ada sejak abad ke-17 berdasarkan peta dari Isaac de Graaf. Sisa struktur benteng yang ditemukan oleh van de Wall ketika itu berupa sisa pondasi saja. Tampaknya lokasi benteng ini digunakan sebagai tangsi militer hingga ditariknya sebuah garnisun pada tahun 1866 (de Wall, 1928: 281).

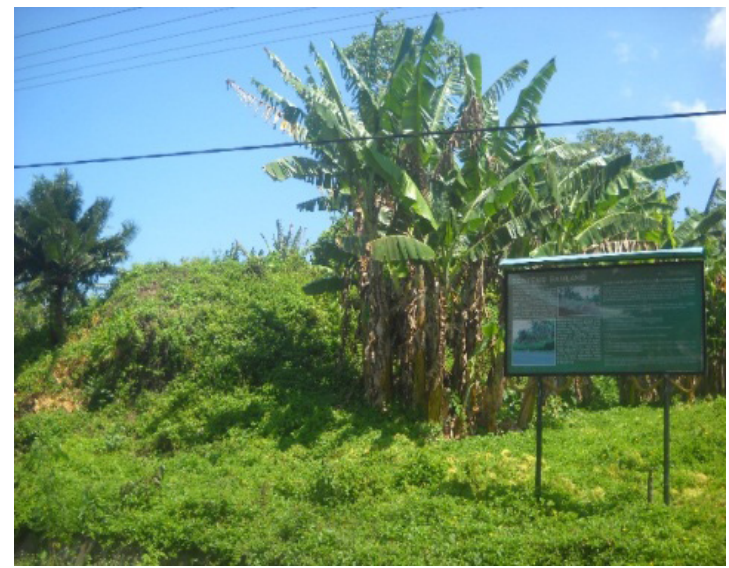

Gambar 4. Tampak depan Benteng Gamlamo Desa Gamlamo, Jailolo. (Sumber: Dokumen Balai Arkeologi Ambon, 2015)

Informasi lain dari penelitian sebelumnya yang menyebutkan titik lokasi tambahan di wilayah pesisir barat Pulau Halmahera, yaitu inventarisasi benteng yang dilakukan oleh Pusat Dokumentasi Arsitektur yang menyebut tujuh titik lokasi, yaitu Gamkonora, 
Sabuga, Jailolo (Gamlamo), Sidangoli, Dodinga, Akelamo (Oba), Payahe (Pusat Dokumentasi Arsitektur, 2010: 187 dan 194-5). Sementara itu, penelitian yang dilakukan Pusat Arkeologi Nasional tahun 2006, mengidentifikasi dua titik lokasi benteng di Kota Jailolo (Tim Penelitian, 2006b).

Informasi tambahan yang diperoleh berdasarkan dua hasil penelitian tersebut adalah keberadaan Benteng Gamkonora di bagian utara, satu titik lokasi benteng di bagian tengah (Kota Jailolo), serta dua benteng yaitu Akelamo dan Payahe di bagian selatan pesisir barat Pulau Halmahera. Dengan demikian, jumlah keseluruhan titik lokasi keberadaan benteng adalah delapan titik lokasi.

Meski, informasi tentang keberadaan dua benteng di Kota Jailolo berdasarkan hasil penelitian Pusat Arkeologi Nasional (2006b) tidak menyebut secara jelas tentang lokasinya, namun berdasarkan penelusuran sejarah yang bersumber dari van de Wall (1928) ditemukan struktur yang diduga bagian dari benteng di Desa Gufasa yang disebutnya Benteng Gofasse atau Gufasa (Wall, 1928: 281). Berdasarkan dua informasi, yaitu hasil Pusat Arkeologi Nasional dan sumber sejarah dari van de Wall, maka titik lokasi benteng kedua (selain Gamlamo) di Kota Jailolo adalah di lokasi yang saat ini dijadikan sebagai markas koramil di Desa Gufasa (Kota Jailolo).

\section{Sebaran Benteng Kolonial Eropa di Pesisir Barat Pulau Halmahera}

Kondisi benteng yang relatif utuh hanya ada di Lako Akelamo, yaitu Benteng Sabuga dan Benteng Tabuga. Sementara itu, benteng-benteng lain di antaranya benteng Jailolo (Gamlamo), Sidangoli, dan Dodinga hanya menyisakan beberapa struktur berupa dinding benteng (Tim Penelitian, 2015). Sementara itu, laporan inventarisasi benteng oleh PDA menyebutkan bahwa kondisi benteng yang ada di Gamkonora, Akelamo (Oba), dan Payahe hanya menyisakan sisa struktur pondasi. Benteng lain yaitu Benteng Gufasa dapat diidentifikasi berdasarkan informasi sumber historis. Dengan melihat kondisi benteng-benteng tersebut, sulit untuk mengetahui bentuk atau melakukan rekonstruksi bentuk benteng. Dengan demikian, analisis bentuk benteng dilakukan dengan mengkomparasikan hasil observasi di lapangan dan penelusuran sumbersumber historis.

Kondisi benteng di Gamkonora, Tabuga, Oba, dan Payahe hanya menyisakan sisa struktur sehingga sulit mengetahui bentuk dan jenisnya. Benteng Sabuga, Gofasa, Gamlamo, Dodinga, dan Sidangoli dapat dikelompokkan Klein Fort. Hal ini dapat dilihat dari sisa stuktur yang masih menampilkan dinding benteng dan bastion benteng. Sementara itu, titik-titik lokasi keberadaan benteng dapat dilihat berdasarkan keletakan geografis-nya, keseluruhan titik lokasi benteng berada di wilayah pesisir barat Pulau Halmahera dengan posisi geografis, yaitu bagian utara, tengah, dan selatan. Bagian utara terdapat Benteng Gamkonora, Sahu (Sabuga dan Tabuga); bagian tengah terdapat Benteng Gufasa, Gamlamo, dan Sidangoli; serta bagian selatan terdapat benteng Dodinga, Oba, dan Payahe. 


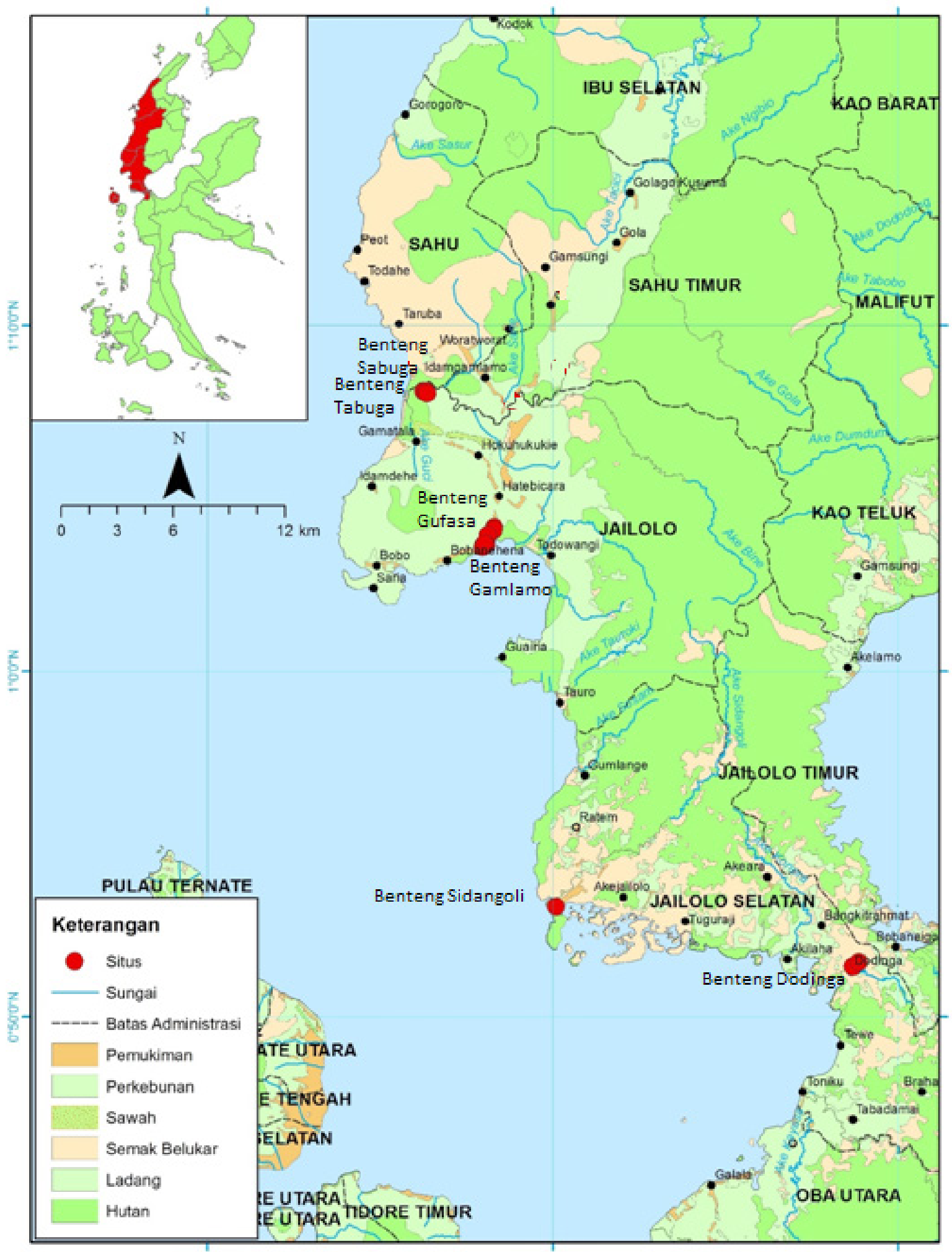

Gambar 5. Peta sebaran benteng di wilayah pesisir barat Pulau Halmahera.

(Sumber: Dokumen Balai Arkeologi Ambon, 2015) 
Keletakan geografis sebaran benteng ini menunjukkan bahwa daerah pesisir barat Pulau Halmahera merupakan wilayah yang berhadapan langsung dengan wilayah Ternate dan Tidore sehingga pemilihan lokasi benteng dimaksudkan untuk mengantisipasi serangan dari arah barat. Asumsi ini semakin kuat jika memperhatikan sebaran benteng yang tepat berhadapan dengan Pulau Ternate dan Tidore. Lima dari delapan titik sebaran benteng di wilayah ini, yaitu Gofasa, Gamlamo, Dodinga, Sidangoli, dan Oba yang berhadapan langsung dengan kedua pulau tersebut.

Keletakan benteng secara umum berada di lokasi dengan kategori daerah pesisir, meski keletakannya berada di daerah perbukitan namun lokasi benteng tetap dapat memantau wilayah perairan, kecuali beberapa benteng yang berada di lokasi yang tersembunyi dari pantauan arah laut yaitu Sabuga, Tabuga, Gamlamo, dan Dodinga. Keletakan benteng baik yang berada di daerah pesisir yang berhadapan langsung dengan perairan maupun benteng yang berada di daerah pesisir namun tersembunyi serta benteng yang berada di daerah perbukitan. Hal ini dimungkinkan karena topografi Pulau Halmahera yang merupakan pulau terbesar di wilayah ini dengan daerah pesisir memiliki dataran yang cukup luas sehingga banyak daerah-daerah tersembunyi dari arah laut yang dapat dipilih.

Selain pertimbangan geografis, pertimbangan lain berkaitan dengan strategi pertahanan karena keletakan benteng yang tersembunyi menjadikan benteng sulit dipantau langsung dari arah laut. Khusus untuk Benteng Sabuga dan Tabuga yang berada dekat dengan aliran sungai sehingga kedua benteng ini sekaligus berfungsi sebagai pos yang dapat menghubungkan wilayah pedalaman dengan wilayah perairan.

\section{Benteng Gamlamo: Benteng Terkuat dan Pusat Kesultanan Jailolo}

Dalam berbagai catatan sejarah disebutkan bahwa kerajaan-kerajaan yang ada di wilayah Maluku Utara sering terjadi konflik termasuk Jailolo yang sering mendapat serangan dari Ternate. Salah satu sumber sejarah yang menyampaikan hal ini adalah catatan perjalanan Tome Pires yang ditulis pada paruh awal abad ke-16 (Cortesao, 2015: 305). Adnan Amal (2010), bahkan menyebut bahwa konflik antara Jailolo dan Ternate telah berlangsung lama bahkan sejak masa pra-kolonial. Serangan Ternate terhadap Jailolo pada masa prakolonial telah terjadi sebanyak enam kali yang dimulai sejak tahun 1284. Konflik ini terjadi dalam rentang waktu \pm 300 tahun dan serangan terakhir pada tahun 1551, berkat bantuan Portugis, Ternate berhasil menganeksasi dan menjadikan wilayah Jailolo sebagai bagian dari kekuasaan Ternate (Amal, 2010: 27-28 dan 34). Pascakekalahan ini, masyarakat Jailolo terutama suku Wayoli banyak yang keluar dari wilayah Jailolo. Daerahdaerah yang ditinggalkan kemudian diisi oleh eksodus besar-besaran masyarakat Ternate (Fara, 2014: 63).

Dalam pandangan Portugis, serangan yang terjadi pada tahun 1551 merupakan serangan terbesar yang pernah dilakukan di Maluku. Hal ini tampak pada 
pengakuan Portugis yang menyebutkan bahwa pemimpin Jailolo saat itu yakni Katarabumi adalah yang paling kuat di seluruh Kepulauan (Maluku). Selain pemimpin yang kuat, Kesultanan Jailolo pada saat itu juga memiliki benteng yang sulit ditembus hingga pada akhirnya pasukan gabungan Ternate-Portugis berhasil menaklukkan benteng ini (Andaya, 2015: 168-169). Menghadapi serangan besar ini, Katarabumi memperkuat benteng tersebut dengan membuat dinding luar yang terbuat dari tanah dan batu yang di atasnya berdiri tembok dengan dua kubu pertahanan (bulwark). Benteng ini juga dilengkapi dengan 100 pucuk senjata laras panjang, 18 pucuk meriam serta sebuah mortir, dan berbagai senjata yang didatangkan dari Pulau Jawa, berikut berbagai peralatan untuk mengatasi kepungan (Amal, 2010: 35; Andaya, 2015: 169).

Sumber historis sebagaimana dikemukakan oleh ahli sejarah di atas tidak menyebut tentang nama serta lokasi keberadaan benteng yang menjadi pusat pertahanan Katarabumi ketika menghadapi serangan TernatePortugis. Jika mengamati deskripsi tentang benteng pertahanan Katarabumi, jelas bahwa pembuatan benteng ini memadukan antara teknologi pembuatan benteng oleh masyarakat lokal (pribumi) dan juga oleh bangsa Eropa. Pada umumnya, masyarakat lokal di nusantara membuat benteng dengan cara sederhana, yaitu membuat gundukan tanah atau memanfaatkan kondisi alam sebagai pusat pertahanan. Sementara itu, teknologi pembuatan benteng yang dilakukan oleh bangsa Eropa umumnya membuat benteng dengan membangun tembok keliling tinggi yang terbuat dari susunan batu dengan menggunakan perekat campuran pasir dan kapur bakar.

Sebaran benteng yang ada di pesisir barat Halmahera menunjukkan bahwa terdapat setidaknya delapan titik lokasi benteng di wilayah ini, di antaranya satu benteng di Gamkonora, dua benteng di Sahu, dua benteng di Jailolo, satu benteng di Sidangoli, satu benteng di Dodinga, satu benteng di Oba, dan satu benteng di Payahe (Tim Penelitian, 2015). Secara geografis, keletakan titik sebaran benteng terbagi atas wilayah utara, tengah dan selatan. Titik sebaran ini didasarkan pada posisi Jailolo yang ada di bagian tengah. Dengan demikian, benteng yang menjadi pusat pertahanan Katarabumi pada saat serangan besar-besaran yang dilakukan oleh pasukan gabungan Ternate-Portugis tentunya merujuk pada benteng yang ada di Jailolo saat ini.

Hasil survei arkeologi dan penelusuran sumber sejarah menunjukkan bahwa di Kota Jailolo terdapat dua titik yang merupakan lokasi keberadaan benteng, yaitu Desa Gamlamo dan Desa Gufasa. Benteng yang ada di Desa Gamlamo masih dapat disaksikan dengan adanya sisa struktur berupa pondasi serta gundukan tanah yang terletak $\pm 500 \mathrm{~m}$ sebelah timur Masjid Tua Gamlamo. Benteng ini berada pada ketinggian 24 $\mathrm{m} \mathrm{dpl}$, dengan jarak $\pm 5 \mathrm{~km}$ dari pantai (Tim Penelitian, 2015). Sementara itu, keberadaan Benteng Gufasa yang telah telah ada sejak abad ke-17, sebagaimana ditunjukkan pada peta dari Isaac de Graaf. Sisa struktur benteng yang ditemukan oleh van de Wall ketika itu hanya berupa sisa 
pondasi saja. Tampaknya lokasi benteng ini digunakan sebagai tangsi militer hingga ditariknya sebuah garnisun pada tahun 1866 (Wall, 1928: 281). Merujuk pada informasi ini, kemungkinan yang dimaksudkan oleh van de Wall adalah lokasi yang saat ini menjadi markas koramil yang ada di Desa Gufasa-Jailolo. Dengan demikian, untuk mengetahui keberadaan benteng yang menjadi pusat pertahanan Katarabumi pada abad ke16, dapat ditelusuri berdasarkan data arkeologi dan sumber historis.

Perbandingan data arkeologi pada dua benteng ini yaitu Benteng Gamlamo dan Benteng Gufasa, tampaknya data kontekstual Benteng Gamlamo lebih menguatkan asumsi sebagai pusat kesultanan. Di daerah ini terdapat masjid tua dan makam tua. Demikian halnya kondisi lingkungan di sekitar Benteng Gamlamo yang berada di daerah ketinggian dengan kondisi lahan yang berkontur dan cukup jauh dari pantai. Sementara itu, titik lokasi Benteng Gufasa lebih didominasi oleh tinggalan arkeologi periode masa Kolonial Belanda, di antaranya bekas penjara, tangsi militer, dan bekas rumah sakit (Tim Penelitian, 2015).

\section{Benteng Sabuga dan Perlawanan Sultan Ternate (Kaitjil Amsterdam) terhadap VOC}

Pada kesempatan penelitian tahun 2006, diperoleh informasi bahwa benteng ini disebut dengan Benteng Say Loko yang berasal dari bahasa Sahu, say berarti pemantauan dan loko berarti matamata. Tradisi tutur juga menyebutkan pascahengkangnya bangsa Portugis, salah seorang keturunan Sultan Ternate tinggal di benteng tersebut hingga wafat (Tim Penelitian, 2006a). Informasi tutur ini tentu dapat diinterpretasikan bahwa masyarakat di wilayah Sahu memiliki hubungan baik dengan Kesultanan Ternate pada masa lalu.

Hubungan baik ini dapat ditelusuri pascakekalahan Jailolo. Wilayahwilayah yang berada di bawah kekuasaan Kesultanan Ternate di antaranya Gamkonora, Sahu, dan Jailolo, menempatkan sangaji (atau mengangkat penguasa setempat) sebagai perwakilannya. Kesultanan Ternate juga pernah menjadikan wilayah pesisir barat Halmahera sebagai pusat perlawanan, baik ketika menghadapi Spanyol (16061620), maupun ketika menghadapi VOC (1679-1681). Periode pertama ketika Sultan Saidi berkuasa sebagai Sultan Ternate, terjadi serangan Tidore-Spanyol ke pusat kekuasaan Ternate. Sultan Saidi memilih mundur ke Jailolo kemudian ke Sahu pada Maret 1606 dan pada bulan Mei, Sultan Saidi ditangkap dan wilayah Sahu kemudian diduduki oleh Spanyol tahun 1620 (Amal, 2010: 102, 104).

Sementara itu, catatan van de Wall (1928), menyebutkan bahwa VOC berhasil merebut Benteng Sabuga pada tahun 1611 dan selanjutnya meninggalkan benteng ini pada tahun 1618. Dengan demikian, tampaknya perebutan atas wilayah ini sangat dinamis pada masa itu.

Periode berikutnya adalah ketika Sultan Ternate yaitu Sultan Sibori Amsterdam memiliki hubungan politik yang buruk dengan sekutu barunya yaitu VOC. Perselisihan dengan Padtbrugge sebagai penguasa VOC di Ternate, memaksa Sultan Amsterdam untuk 
melakukan perlawanan dan memilih mundur ke wilayah pesisir barat Pulau Halmahera. Pada periode ini, wilayah Jailolo termasuk Gamkonora dan Sahu kembali menjadi pusat perlawanan Kesultanan Ternate. Ketiga pusat atau pos perlawanan Sultan Ternate secara geografis berada di wilayah pesisir barat Pulau Halmahera, dan dari ketiga pos tersebut Sahu adalah "pos terkuat di Maluku". Perlawanan Sultan Amsterdam berakhir pada Juli tahun 1680, VOC berhasil merebut pos-pos tersebut, dan setelah menduduki Benteng Sahu, VOC memilih kembali ke Ternate (Andaya, 2015: 255). Sultan Amsterdam sendiri ditangkap di Sahu dan bersama keluarganya dibuang ke Batavia pada 30 Agustus 1681 (Amal, 2010: 142). Keberhasilan VOC mematahkan perlawanan Sultan Amsterdam di pesisir barat Pulau Halmahera kemungkinan menjadi pertimbangan utama bagi VOC untuk mendirikan tugu yang berada tidak jauh dari Benteng Sabuga.

Dalam pandangan Andaya (2015), meski perlawanan Sultan Amsterdam tidak berlangsung lama (hanya tiga tahun), pascakekalahan ini, hubungan TernateVOC dianalogikan sebagai hubungan antara ayah (di pihak VOC) dan anak (di pihak Ternate). Dalam koteks hubungan politik-kekuasaan lokal, perjanjianperjanjian pascakekalahan tersebut menjadikan VOC memperoleh hak untuk mengesahkan penguasa-penguasa di beberapa daerah termasuk di Jailolo dan Sahu (Andaya, 2015: 264), termasuk pula pengangkatan Sultan Ternate yang harus mendapat persetujuan VOC (Amal, 2010: 142). Dengan demikian, implikasi kekalahan pihak Ternate telah memantapkan hegemoni kekuasaan VOC atas Kepulauan Rempah-Rempah.

Periode historis wilayah Sahu memberi petunjuk tentang peran Benteng Sabuga sebagai pusat pertahanan yang kokoh sehingga menjadi pilihan utama - setidaknya bagi pihak Ternate. Selain karena daerah ini menjadi daerah kekuasaan Ternate pascakekalahan Jailolo pada tahun 1551, posisi strategis Benteng Sabuga juga menjadi pertimbangan utama atas pilihan tersebut. Posisi Benteng Sabuga berada di daerah aliran sungai yang tidak terlalu jauh dari pantai. Posisi ini menjadikan Benteng Sabuga sebagai pusat pertahanan yang ideal terutama jika dikaitkan dengan strategi perang laut pada masa itu yang menjadi orientasi utama di wilayah kepulauan seperti Maluku. Topografi wilayah Sahu dengan wilayah dataran di daerah pesisir dan daerah perbukitan memungkinkan bagi pihak yang bertahan untuk mundur ke daerah perbukitan.

Hasil penelitian dengan menggunakan metode ekskąvasi yang dilakukan pada 2009 memberi informasi bahwa wilayah ini telah eksis sejak masa pra-kolonial. Temuan-temuan berupa keramik asing yang diduga berasal dari abad ke 12-13 $\mathrm{M}$, serta temuan gerabah lokal dan adanya konsentrasi kulit kerang pada lapisan akhir. Dalam konteks peran wilayah, lokasi Benteng Sabuga merupakan wilayah kekuasaan Kesultanan Jailolo yang cukup strategis dan memiliki potensi sumber daya yang penting untuk eksistensi dan pengembangan wilayah (Handoko, 2010: 13, 20). 
Terkait dengan temuan kulit kerang, hasilpenelitian prasejarah mengemukakan bahwa persebaran penggunaan kerang sebagai peralatan sehari-hari bermula dari wilayah Maluku Utara. Selain itu, potensi sumber daya pangan berupa sagu merupakan sumber pangan utama yang telah menjadi konsumsi utama di kawasan ini sejak masa prasejarah (Noerwidi, 2014: 4-5).

Peran wilayah Sahu yang juga berhubungan dengan Benteng Sabuga dapat ditelusuri pada periode selanjutnya yaitu pada periode perlawanan Sultan Nuku dibantu oleh Inggris menghadapi Belanda-Ternate pada akhir abad ke-18. Sultan Nuku pada saat itu, menyusun strategi blokade terhadap kedudukan Belanda-Ternate di pusat kekuasaan mereka di Pulau Ternate. Salah satu langkah yang ditempuh oleh pasukan Tidore-Inggris adalah menyerang wilayah Sahu untuk mencegah pengiriman logistik ke Ternate. Wilayah pesisir barat Pulau Halmahera dikenal sebagai lumbung padi dan sagu bagi Ternate (Amal, 2010: 194). Hal ini, sekaligus menegaskan bahwa wilayah pesisir barat Halmahera sejak dulu merupakan sumber pangan utama di wilayah Maluku bagian utara.

\section{Benteng Dodinga: Penjaga Tapal Batas}

Dalam perjalanan panjang sejarah perebutan wilayah yang melibatkan pilar kekuasaan di wilayah Maluku Utara, terdapat satu wilayah yang diakui secara bersama sebagai daerah tapal batas. Dua kekuatan utama di wilayah ini yaitu Ternate dan Tidore saling mengklaim bahwa mereka memiliki daerah kekuasaan di Pulau Halmahera sebagai pulau terbesar di Maluku Utara. Bagian selatan merupakan wilayah kekuasaan Tidore, dan bagian utara merupakan wilayah Ternate. Klaim wilayah Tidore yang ada di bagian selatan Pulau Halmahera berhubungan dengan sejarah terbentuknya kerajaan ini yang pada awalnya terletak di wilayah tersebut.

Menurut catatan Valentijn-Keyzer (1856), bahwa pada mulanya pusat Kerajaan Tidore terletak di Batu Cina, di sebelah selatan Dodinga (Amal, 2010: 159). Sementara itu, klaim Ternate terhadap bagian utara Pulau Halmahera merupakan bagian dari keberhasilan mereka menguasai Jailolo pascakekalahan Katarabumi pada tahun 1551. Dalam pandangan pihak Ternate, wilayah kekuasaan Jailolo mengacu pada sejarah awal kerajaan ini. Saat itu kekuasaan Jailolo meliputi hampir seluruh Halmahera, yaitu Batu Cina di selatan hingga berbatasan dengan wilayah Kerajaan Loloda di utara (Amal, 2010: 25). Hal inilah kemudian menjadi latar historis yang dapat menjelaskan mengapa wilayah dodinga menjadi daerah tapal batas antara Jailolo, Ternate, dan Tidore.

Keberadaan benteng di wilayah Dodinga dapat ditelusuri dari berbagai sumber sejarah yang menjadi informasi penting untuk menjelaskan peran Dodinga sebagai daerah tapal batas. Salah satunya, bersumber dari van de Wall (1928), bahwa Benteng Dodinga berperan penting dalam pertempuran melawan Sultan Kaitjil Amsterdam dan kemungkinan dibangun oleh Spanyol (Wall, 1928: 281). Sumber historis ini memberi informasi bahwa Dodinga telah menjadi wilayah penting sejak awal masuknya bangsa Eropa di 
Maluku Utara. Jika disebutkan benteng ini dibangun oleh Spanyol, setidaknya pembangunan benteng berkaitan dengan dua periode pergolakan yang melibatkan Spanyol di wilayah ini. Periode pertama sekitar pertengahan abad ke-16, ketika pasukan Ternate-Portugis menyerang Jailolo yang saat itu mendapat bantuan dari pihak Spanyol bersama dengan Tidore. Periode kedua sekitar awal abad ke-17 ketika Spanyol bersama Tidore menyerang kedudukan Sultan Ternate hingga ke wilayah Jailolo (Halmahera). Informasi historis lain menyebutkan sekitar tahun 1527, pihak Spanyol memberi bantuan persenjataan dan pertahanan, bahkan melatih pasukan Jailolo dalam menghadapi kemungkinan serangan dari pihak lain (Amal, 2010: 2930). Dengan demikian, informasi ini tentu lebih menguatkan asumsi bahwa Benteng Dodinga dibangun pada periode awal pergolakan antara Jailolo-Spanyol-Tidore dengan Ternate-Portugis. Sementara itu, Andaya (2015), menyebut pada tahun 1686 terdapat dua benteng di Dodinga: satu benteng dipelihara oleh VOC dan satu benteng lainnya dipelihara oleh Ternate. Keberadaan benteng di wilayah ini dimaksudkan untuk mengawasi jalur darat yang menghubungkan antara pesisir barat dan timur Pulau Halmahera (Andaya, 2015: 114).

Tahun 1686merupakan periode tenang di Maluku, saat itu VOC telah meredam perlawanan Sultan Kaitjil Amsterdam. Keberadaan kedua benteng di wilayah Dodinga berkaitan dengan kepentingan antara Ternate dan VOC. Pertama bahwa kedua pihak berkepentingan untuk mengawasi wilayah tersebut sebagai tapal batas antara Ternate-VOC dan Tidore.
Kedua, masing-masing pihak (Ternate dan VOC) memiliki kepentingan atas wilayah tersebut. Pihak Ternate, misalnya berkepentingan tetap menjaga wilayah ini karena penduduknya adalah orang-orang yang dipindahkan dari Halmahera Timur hingga Halmahera Utara oleh pihak Ternate pascakekalahan Katarabumi pada 1551 sehingga wilayah ini merupakan bagian dari struktur-kekuasaan Ternate dengan adanya Sangaji di Dodinga (Amal, 2010: 114). Sementara itu, VOC berkepentingan untuk menjaga wilayah ini karena hubungan dengan Kesultanan Tidore belum sepenuhnya dapat diatasi. Hal ini terbukti ketika perlawanan Sultan Nuku (Tidore) mulai bergolak pada pertengahan abad ke-18.

Penjagaan atas wilayah ini bahkan berlanjut pada masa Pemerintahan Belanda, karena jalur darat di wilayah ini mulai ramai sebagai rute perdagangan yang menghubungkan antara pesisir barat dan timur Halmahera. Benteng dengan penjagaan oleh Pemerintah Belanda kini tidak ada bekasnya lagi karena digunakan untuk membangun jalan (Amal, 2010: 304). Saat ini, benteng di Dodinga hanya menyisakan satu benteng saja di daerah perbukitan di Desa Dodinga, selain sisa struktur terdapat dua meriam yang berada di depan Kantor Desa Dodinga (Tim Penelitian, 2015).

\section{SIMPULAN}

Perjalanan sejarah Kerajaan Jailolo sejak masa Kolano hingga Kesultanan diwarnai dengan konflik berkepanjangan. Konflik pertama menyebabkan kehancuran paling signifikan terhadap struktur pemerintahan. Gelar sultan 
tidak lagi menjadi hak penguasa Jailolo dan sebagai gantinya penguasa Jailolo ditunjuk menjadi sangaji atau perwakilan Sultan Ternate. Selanjutnya pada masa kehadiran Belanda di wilayah ini, mereka memperoleh hak untuk mengesahkan sangaji di Jailolo. Hak ini diperoleh setelah Belanda berhasil meredam perlawanan Sultan Kaitjil Amsterdam pada tahun 1680. Praktis, kondisi ini menyebabkan Jailolo berada dalam kuasa penuh baik pihak Ternate maupun Belanda.

Jejak perjalanan sejarah perebutan wilayah Kesultanan Jailolo ini tampak pada sebaran benteng di pesisir barat Halmahera. Merunut pada periodisasi benteng, yaitu Gamkonora, Sabuga, Tabuga, Gamlamo, dan Dodinga adalah benteng sejak masa Portugis-Spanyol di Maluku Utara. Diduga benteng-benteng ini dibangun oleh Spanyol sebagai bagian dari bantuan sistem pertahanan pihak Spanyol kepada Jailolo. Benteng-benteng ini menjadi pusat-pusat pertahanan masa pergolakan baik antara Ternate (Portugis) melawan Jailolo, maupun antara Ternate (Portugis) melawan Jailolo (Spanyol). Keberadaan Benteng Sabuga dan Tabuga di bagian utara dan Dodinga di bagian selatan Jailolo (sebagai pusat kekuasaan) merupakan titik pengawasan untuk melindungi wilayah Jailolo. Khusus benteng Dodinga berperan sebagaipenjaga tapal batas antara wilayah Jailolo yang dikuasai oleh Ternate dan wilayah Tidore. Demikian halnya Benteng Gamlamo menjadi pusat pertahanan utama Jailolo di wilayah pusat kekuasaannya.

Keberadaan sebaran benteng di wilayah pesisir barat Halmahera menguatkan teori tentang faktor pemilihan lokasi pendirian suatu benteng adalah sebagai berikut. Pertama, bahwa wilayah ini sangat penting baik bagi penguasa lokal (Jailolo dan Ternate) maupun pihak asing (Portugis, Spanyol, dan Belanda). Kedua, berkaitan dengan ancaman yang kemungkinan akan dihadapi. Ketiga, berkaitan dengan strategi yang diterapkan dalam upaya menaklukan atau mempertahankan wilayah ini untuk perluasankekuasaan. Halinimenunjukkan bahwa dinamika politik yang terjadi di wilayah ini menjadi aspek penting dalam pemilihan lokasi pendirian benteng. Demikian, sebagai akhir dari tulisan ini dapat dinyatakan bahwa sebaran benteng di wilayah pesisir barat Pulau Halmahera dapat menggambarkan peran wilayahwilayah yang dulunya menjadi wilayah penyangga tidak hanya bagi tumbuh dan berkembangnya Kesultanan Jailolo tetapi juga wilayah lain termasuk Kesultanan Ternate dan Tidore. Setidaknya tulisan ini telah memberi sumbangan pemikiran bahwa pesisir barat Pulau Halmahera telah berperan penting dalam dinamika sejarah budaya di Maluku Utara.

\section{DAFTAR PUSTAKA}

Abbas, Novida. 2001. Dutch Forts of Java a Locational Study. Thesis. Department of History, Faculty of Arts and Social Sciences. Singapore: National University of Singapore.

Amal, M. A. 2010. Kepulauan Rempah-Rempah: Perjalanan Sejarah Maluku Utara 12501950. Jakarta: Kepustakaan Populer Gramedia. 
Ambary, H.M. 1998. Menemukan Peradaban: Jejak Arkeologis dan Historis. Jakarta: Logos Wacana.

Andaya, L.Y. 2015. Dunia Maluku: Indonesia Timur Pada Zaman Modern Awal. Edisi Terjemahan. Yogyakarta: Penerbit Ombak.

Cortesao, Armando. 2015. Suma Oriental: Karya Tome Pires: Perjalanan dari Laut Merah ke Cina dan Buku Francisco Rodrigues. Edisi Terjemahan. Yogyakarta: Penerbit Ombak.

Fara, S.D. 2014. Sejarah Kerajaan Jailolo di Bawah Kekuasaan Kolano Katarabumi (Catabruno) Tahun 1534-1551. Skripsi. Program Studi Pendidikan Sejarah, Fakultas Keguruan dan Ilmu Pendidikan. Salatiga: Universitas Satya Wacana.

Handoko, W. 2010. Perebutan Wilayah Pada Masa Transisi Kekuasaan Islam-Kolonial di Wilayah Kerajaan Jailolo (Studi Kasus: Studi Benteng Lako Akelamo, Kabupaten Halmahera Barat. Kapata Arkeologi, 6 (11): 1-24.

Mansyur, Syahruddin. 2011. Jejak Tata Niaga Rempah-Rempah dalam jaringan Perdagangan Masa Kolonial di Maluku. Kapata Arkeologi, 7 (13): 20-39.

Mansyur, Syahruddin. 2014. Sistem Perbentengan dalam Jaringan Niaga Cengkih Masa Kolonial di Maluku. Kapata Arkeologi, 10 (2): 85-98.

Marihandono, D. 2008. Perubahan Peran dan Fungsi Benteng dalam Tata Ruang Kota. Wacana: Jurnal Ilmu Pengetahuan Budaya, 10 (1): 144-160.

Noerwidi, S. 2014. Migrasi Austronesia dan Implikasinya Terhadap Perkembangan Budaya di Kepulauan Indonesia. Amerta: Jurnal Penelitian dan Pengembangan Arkeologi, 32 (1): $1-10$.

Pusat Dokumentasi Arsitektur. 2008. Field Survey Report Mid Year Evaluation: The Inventory and Identification of Fort in Indonesia. Makalah Workshop Hasil Indentifikasi Benteng di Indonesia Timur. Jakarta, 12 Juli 2008: Pusat Dokumentasi Arsitektur, PAC - Architects and Consultants, dan Direktorat Jenderal Sejarah dan Purbakala Departemen Kebudayaan dan Pariwisata.

Pusat Dokumentasi Arsitektur. 2010. Inventory and Identification Forts in Indonesia. Jakarta: Pusat Dokumentasi Arsitektur; Direktorat Peninggalan Purbakala Kementerian Kebudayaan dan Pariwisata; PAC Architects and Consultants.

Sharer and Ashmore. 1980. Fundamentals of Archaeology. California: The Benyamin Publishing Company Inc.

Tim Penelitian. 2006a. Arkeologi di Kecamatan Ibu Selatan dan Kecamatan Sahu Barat, Kabupaten Halmahera Barat, Propinsi Maluku Utara. Laporan Penelitian. Ambon: Balai Arkeologi Ambon.

Tim Penelitian. 2006b. Jaringan Perdagangan Masa Kesultanan Ternate-Tidore-Jailolo di Wilayah Maluku Utara Abad ke-16 hingga Abad ke-19. Tahap I. Laporan Penelitian Arkeologi. Jakarta: Pusat Penelitian dan Pengembangan Arkeologi Nasional. 
Tim Penelitian. 2015. Menelusuri Jaringan Perbentengan di Pesisir Barat Pulau Halmahera. Laporan Penelitian Arkeologi. Ambon: Balai Arkeologi Ambon.

Wall, V.I. van de. 1928. de Nederlandsche Oudheden in de Molukken. Gravenhage: Martinus Nijhoff. 